\title{
Effects of butyrate supplementation on blood glucagon-like peptide-2 concentration and gastrointestinal functions of lactating dairy cows fed diets differing in starch content
}

\author{
R. Fukumori, ${ }^{1}$ M. Oba, ${ }^{2 *} \odot$ K. Izumi, ${ }^{3} \odot$ M. Otsuka, ${ }^{1}$ K. Suzuki, ${ }^{1}$ S. Gondaira, ${ }^{1}$ H. Higuchi, ${ }^{1}$ and S. Oikawa ${ }^{1}$ \\ ${ }_{1}^{1}$ Department of Veterinary Medicine, School of Veterinary Medicine, Rakuno Gakuen University, Ebetsu, Japan 069-8501 \\ ${ }^{2}$ Department of Agricultural, Food and Nutritional Science, University of Alberta, Edmonton, AB, Canada T6G 2P5 \\ ${ }^{3}$ Department of Sustainable Agriculture, College of Agriculture, Food and Environment Sciences, Rakuno Gakuen University, Ebetsu, \\ Japan 069-8501
}

\section{ABSTRACT}

The objective of this study was to evaluate effects of butyrate supplementation on plasma concentration of glucagon-like peptide-2 (GLP-2), apparent total-tract digestibility, and responses to a grain challenge of lactating dairy cows fed diets differing in starch content. Eight Holstein cows averaging $58.6 \pm 9.96 \mathrm{~d}$ in milk (4 primiparous cows fitted with rumen cannula and 4 multiparous intact cows) were blocked by parity and assigned to one of two $4 \times 4$ Latin squares balanced for carryover effects with a $2 \times 2$ factorial arrangement of treatments. Treatments were dietary starch content [20.6 vs. $27.5 \%$, respectively, for low starch (LS) and high starch (HS)] and butyrate supplementation (butyrate vs. control) with 21-d periods. Butyrate was provided as Gustor BP70 WS (Norel, S.A., Madrid, Spain), containing $70 \%$ sodium butyrate and $30 \%$ fatty acid mixture, at $2 \%$ of dietary dry matter (providing butyrate at $1.1 \%$ of dietary dry matter), and control premix contained $70 \%$ wheat bran and $30 \%$ fatty acid mixture. Feeds, orts, and fecal samples were collected from d 17 to 19 to determine apparent total-tract nutrient digestibility. Blood and rumen fluid samples were collected on d 19. The baseline of dry matter intake (DMI) was determined as average DMI from d 17 to 19 for each cow, and cows were feed-restricted at $60 \%$ of the baseline DMI on d 20, and a grain challenge was conducted by providing steam-flaked corn grain at $0.6 \%$ of body weight, on an as-fed basis, in addition to each treatment diet on d 21, and blood and ruminal fluid samples were collected. The interaction of dietary starch content by butyrate supplementation was significant for plasma GLP-2 concentration, being greater

Received September 29, 2019.

Accepted December 18, 2019.

*Corresponding author: moba@ualberta.ca for cows fed butyrate with the HS diet than those fed the other 3 diets. Cows fed butyrate increased nbutyrate concentration in the ruminal fluid and tended to increase dry matter and organic matter digestibility compared with the control. During the grain challenge, rumen endotoxin concentration increased over time and was higher for cows fed the HS diets compared with those fed LS diets. However, response variables related to inflammation were not affected by the grain challenge. However, serum haptoglobin, lipopolysaccharidebinding protein, and serum amyloid-A concentrations were greater for cows fed butyrate with the LS diet, but not for those fed the HS diet. These results indicate that butyrate supplementation may increase plasma GLP-2 concentration for cows fed HS diets, and totaltract digestibility regardless of dietary starch content. However, butyrate supplementation did not mitigate inflammation in this study.

Key words: butyrate, glucagon-like peptide-2, gut inflammation, nutrient digestibility

\section{INTRODUCTION}

High-producing dairy cows are often fed high-starch (HS) diets to meet their energy demand for milk production and maintain body condition. However, HS diets often cause SARA because they are rapidly fermented to decrease rumen $\mathrm{pH}$, alter microbial flora, and increase concentration of endotoxin (also called LPS) in the ruminal fluid (Khafipour et al., 2009). The increased LPS and low $\mathrm{pH}$ would impair barrier function of gastrointestinal epithelium in vitro (Emmanuel et al., 2007). The impaired barrier function allows the luminal LPS to enter the blood circulation, and leads to systemic inflammation by promoting the release of proinflammatory cytokines (Eckel and Ametaj, 2016). In addition, mucosa-related lymphoid tissue cells respond with local inflammation via LPS and luminal toll-like receptor signaling pathway (Kurashima et al., 2013). 
Butyrate, one of major VFA produced by bacterial fermentation, is known to enhance epithelial growth in the rumen, abomasum, and small intestine (Sakata and Tamate, 1978; Guilloteau et al., 2009; Górka et al., 2011a,b). Moreover, butyrate is known to stimulate secretion of glucagon-like peptide-2 (GLP-2) in calves (Guilloteau et al., 2009; Górka et al., 2011a) and mature sheep (Elsabagh et al., 2017). Glucagon-like peptide-2, secreted from enteroendocrine L-cells mainly located in the distal intestine (Burrin et al., 2003), increased small intestinal blood flow and mucosal growth in weaned calves (Taylor-Edwards et al., 2011). In addition, both butyrate and GLP-2 were reported to play roles in enhancing gut barrier function and reducing gut permeability (Benjamin et al., 2000; Hadjiyanni et al., 2009). Therefore, nutritional strategies increasing butyrate supply or stimulating GLP-2 secretion for dairy cows may mitigate inflammation caused by grain overload.

Butyrate can be supplemented as feed additives such as sodium butyrate or tributyrin (Araujo et al., 2016; Inabu et al., 2019). However, effects of butyrate supplementation have not been extensively studied for lactating dairy cows. We hypothesized that feeding butyrate would increase plasma GLP-2 concentration and enhance gastrointestinal functions such as digestion and anti-inflammatory action in cows fed highly fermentable diets. Therefore, the objectives of the present study were to determine the effect of feeding butyrate on plasma GLP-2 concentration, apparent total-tract nutrient digestibility, and inflammatory responses to a grain challenge in lactating dairy cows fed diets differing in starch content.

\section{MATERIALS AND METHODS}

Cows used in this study were housed at Rakuno Gakuen Field Education and Research Center (Ebetsu, Hokkaido, Japan). All procedures of this study were approved by the Animal Experiment Committee of Rakuno Gakuen University (approval \#VH18C5).

\section{Experimental Design, Animals, and Treatments}

Eight Holstein cows $(1.9 \pm 0.99$ parity, $609 \pm 99.4$ $\mathrm{kg}$ of BW, $3.06 \pm 0.22 \mathrm{BCS}, 58.6 \pm 9.96 \mathrm{DIM}$; mean $\pm \mathrm{SD}$ ), consisting of 4 primiparous cows fitted with a rumen cannula and 4 multiparous intact cows, were used in this study. The experimental design, animal management, and treatments are described in the companion paper (Izumi et al., 2019) in detail. Briefly, cows were blocked by parity (primiparous ruminally cannulated cows in a square, and multiparous intact cows in the other square) and assigned to one $4 \times 4$ Latin square balanced for carryover effects with a $2 \times$
2 factorial arrangement of treatments. Treatments were dietary starch content [20.6 vs. $27.5 \%$, respectively, for low starch (LS) and HS] and butyrate supplementation (butyrate vs. control) with 21-d periods. Butyrate was provided as Gustor BP70 WS (NOREL, S.A., Madrid, Spain), containing $70 \%$ sodium butyrate and $30 \%$ long-chain fatty acid mixture, at $2 \%$ of dietary DM (providing butyrate at $1.1 \%$ of dietary DM), and control premix contained $70 \%$ wheat bran and 30\% long-chain fatty acid mixture. Cows were individually fed the experimental diets as TMR ad libitum to allow for approximately $8 \%$ refusals at 1200 h. Feed refusals were removed at $1100 \mathrm{~h}$ on the following day.

\section{Data and Sample Collection}

Blood samples were collected by tail venipuncture at 0,3 , and $6 \mathrm{~h}$ relative to feeding on $\mathrm{d} 19$ of each period. Blood samples $(5 \mathrm{~mL})$ were collected in heparinized evacuated tubes (Terumo, Tokyo, Japan). Tubes were immediately placed in ice and aprotinin (500 Kallikrein inhibitor units/mL of blood; Sigma-Aldrich Inc., Tokyo, Japan) was added as an inhibitor of peptide degradation. The tubes were then centrifuged at 1,800 $\times g$ for $15 \mathrm{~min}$ at $4^{\circ} \mathrm{C}$. The harvested plasma was stored at $-80^{\circ} \mathrm{C}$ until analyses to determine plasma GLP-2 concentration.

At the same time point of blood collection, rumen fluid samples were collected via rumen cannula from the ventral sac using a hand-made syringe equipped with a $30-\mathrm{cm}$ silicone tube on a rubber dropper. $\mathrm{Ru}-$ minal contents were strained through 4 layers of sterile gauze and divided into 50-mL sterile tubes (Corning Inc., Corning, NY) and kept on ice. The tubes were then centrifuged at $1,800 \times g$ for $15 \mathrm{~min}$ at $4^{\circ} \mathrm{C}$. The supernatant were stored at $-30^{\circ} \mathrm{C}$ until analyses to determine VFA concentration.

From d 17 to 19, apparent total-tract digestibilities of DM, OM, NDF, starch, and CP were determined. Fecal grab samples were collected on every $9 \mathrm{~h}$ for 3 $\mathrm{d}$ to obtain a representative sample accounting for every $3 \mathrm{~h}$ of a 24 -h period. Fecal samples were stored at $-20^{\circ} \mathrm{C}$, then composited for each cow at each period and dried in a forced-air oven for $72 \mathrm{~h}$ at $55^{\circ} \mathrm{C}$. Samples of feed ingredients (corn and grass silage, and mixed concentrate) and orts were collected from d 17 to 19 of each period. The weight of feed offered and orts was recorded daily. Daily samples were stored in a refrigerator, then composited for each period and dried in a forced-air oven at $55^{\circ} \mathrm{C}$ for $48 \mathrm{~h}$. Fecal samples, feed ingredients, and ort samples were then ground to pass through a $1-\mathrm{mm}$ screen.

Ruminal $\mathrm{pH}$ was continuously measured using Small Ruminal pH Data Loggers (SRL T-9, Dascor, Escon- 
dido, CA) every 2 min throughout sample collection period, for 4 fistulated cows as described by Penner et al. (2006). All pH probes were calibrated at $\mathrm{pH} 4.01$ and 6.86 before and after ruminal $\mathrm{pH}$ measurements. Mean, minimum, and maximum $\mathrm{pH}$ values, and the duration and area under the curve when the rumen $\mathrm{pH}$ fell below 5.8 for each 24-h period (area under the curve $<\mathrm{pH} 5.8)$ were determined as described by Penner et al. (2007).

\section{Grain Challenge}

On d 21 of each period, a grain challenge was conducted. Baseline DMI was determined for each cow by averaging DMI from d 17 to 19 , and cows were feedrestricted at $60 \%$ of the baseline DMI on $\mathrm{d} 20$. On $\mathrm{d} 21$ at $1200 \mathrm{~h}$, steam-flaked corn grain was fed to each cow at $0.6 \%$ of $\mathrm{BW}$ (as fed) to provide a grain challenge. Each cow was then allowed ad libitum access to the treatment diet at $1215 \mathrm{~h}$, the amount of TMR offered was $120 \%$ of the baseline DMI. If cows did not eat all corn grain within $15 \mathrm{~min}$, the refusal was weighed, and placed into the rumen for ruminally cannulated cows, or top-dressed on the TMR for intact cows. Coccygeal blood and rumen fluid samples were collected immediately before $(0 \mathrm{~h})$ and 6,12 , and $24 \mathrm{~h}$ after feeding of steam-flaked corn grain. Blood samples were centrifuged at $1,800 \times g$ for $15 \mathrm{~min}$ at $4^{\circ} \mathrm{C}$ to harvest serum (after allowing to clot at room temperature for $45 \mathrm{~min}$ ) and plasma (using heparinized tubes). The harvested serum and plasma were stored at $-80^{\circ} \mathrm{C}$ until analyses to determine the concentrations of serum tumor necrosis factor $\alpha$ (TNF- $\alpha)$, lipopolysaccharide-binding protein (LBP), haptoglobin $(\mathbf{H p})$, serum amyloid A (SAA), and plasma endotoxin. Another portion of heparinized tubes were immediately processed to isolate PMN. Rumen fluid samples were collected via rumen cannula from the ventral sac using a sterile syringe (5 $\mathrm{mL}$; Terumo) into $15-\mathrm{mL}$ sterile tubes (Corning Inc.) and kept on ice. The tubes were then centrifuged at $1,800 \times g$ for $15 \mathrm{~min}$ at $4^{\circ} \mathrm{C}$. The supernatant were stored at $-30^{\circ} \mathrm{C}$ until analyses to determine endotoxin concentration.

\section{Sample Analyses}

Blood, Plasma, and Serum Concentrations. Plasma GLP-2 concentrations were measured through a solid-phase competition immunoassay with synthetic human GLP-2 (Peptide Institute Inc., Osaka, Japan), europium-labeled human GLP-2, and polystyrene microtiter strips coated with goat anti-rabbit $\gamma$-globulin and anti-rat GLP-2 serum targeting the N-terminal of GLP-2 moiety (Yanaihara Institute Inc., Shizuoka, Ja- pan) as described by Elsabagh et al. (2017). Intra- and interassay CV were 2.7 and $2.2 \%$, respectively, and the detection limit was $0.042 \mathrm{ng} / \mathrm{mL}$. Serum concentrations of variables related to inflammation were measured using an colorimetric assay with their commercially available kits for TNF-a (ab193683-TNF a Bovine ELISA Kit, Abcam, Cambridge, UK), LBP (LBP, various species, ELISA kit, HK503, Hycult Biotech Inc., Wayne, PA), and Hp (Cow Haptoglobin ELISA, HAPT-11, Life Diagnostics Inc., West Chester, PA). Serum SAA concentrations were measured with an automated latex agglutination turbidimetric immunoassay (SAA-1, Eiken Chemical Co., Tokyo, Japan) using an automated clinical chemical analyzer (Hitachi 7170S, Hitachi Ltd., Tokyo, Japan) as described by Christensen et al. (2012).

Rumen VFA Concentrations. Ruminal VFA were measured in samples of ruminal fluid. Concentrations of VFA were determined by GC (G3810, Yanako, Kyoto, Japan) using a 2.0-m (0.34-mm i.d.) glass column (glass column for G-3810; Shimadzu GLC Ltd., Kyoto, Japan) packed with Thermon 3000 Shimalite TPA 60/80 (Shinwa Chemical Industries Ltd., Kyoto, Japan).

Chemical Composition of Feeds, Orts, and Feces. Diet ingredients, fresh TMR, refusals, and fecal samples were dried in a $55^{\circ} \mathrm{C}$ forced-air oven for $72 \mathrm{~h}$ and then ground through a 1-mm screen. The samples were sent to Cumberland Valley Analytical Services (Hagerstown, MD) and analyzed for DM (AOAC International, 2000), ash (AOAC International, 2000), NDF (Van Soest et al., 1991), starch (Hall, 2009), and CP (AOAC International, 2000). Indigestible NDF was determined after $336 \mathrm{~h}$ of in situ digestion using a ruminally cannulated dry cow fed grass hay with a method adapted from Huhtanen et al. (1994), and used as an internal marker to estimate fecal output (Cochran et al., 1986).

Endotoxin Measurements. Endotoxin activities in plasma and rumen fluid were measured by conventional limulus amebocyte lysate (LAL)-kinetic turbidimetric (KTA) and chromogenic assays, respectively. Immediately before testing, plasma and rumen samples were diluted 20- and 10,000-fold in endotoxin-free water (Otsuka distilled water, Otsuka Pharmaceutical Co., Ltd., Tokyo, Japan), respectively, and the dilutions were vortexed for $10 \mathrm{~s}$. Plasma dilutions were then heated for 10 min at $80^{\circ} \mathrm{C}$ to inactivate interfering substances, such as protease inhibitors (Suzuki et al., 2015). The diluted rumen fluids were used for analysis without heating. The endotoxin reference standard (CSE, Control Std Endotoxin, Charles River, Charleston, SC), which contained 10,000 endotoxin units/vial, was used as the positive control. The LAL reagents for LAL KTA (Endosafe KTA2, Charles River) and kinetic chromogenic assay (Endosafe Endochrome-K kit, Charles River) as- 
says were reconstituted with Endotoxin-Specific Buffer Solution (Charles River) to eliminate $\beta$-glucan. Both conventional LAL-based assays were performed on 96well microplates (Endosafe 96-well, flat bottom microplate M9001, Charles River). Endotoxin activity was measured using a microplate reader (Sunrise, Tecan Group Ltd., Männedorf, Switzerland) and EndoScanVTM endotoxin-measuring software (Charles River). The lower limits of detection for this assay in plasma and rumen sample were 0.032 and 0.140 endotoxin units $/ \mathrm{mL}$, respectively. A test result was considered valid when spike recovery and $\mathrm{CV}$ met the accepted criteria; spike recovery: 50 to $200 \%, \mathrm{CV}<25 \%$ (Gee et al., 2008; Cooper et al., 2010; Jimenez et al., 2010; Fukumori et al., 2011).

Abundance of $m R N A$ in Neutrophils. Polymorphonuclear leukocytes were isolated by centrifugation of $20 \mathrm{~mL}$ of heparinized blood samples on a Lympholyte-H (Cedarlane, Burlington, ON, Canada). Cells were separated by centrifugation $(300 \times g$ for 30 min at $20^{\circ} \mathrm{C}$ ) and PMN were transferred to a sterile tube (Becton Dickinson, Tokyo, Japan) and washed in cold PBS. The viability of PMN was assessed using an $\mathrm{AO} / \mathrm{PI}$ cell viability kit (Logos Biosystems, Gyunggi, Korea) and Luna-FL (Logos Biosystems). Neutrophil ratios in PMN were obtained following Diff-Quick staining (Sysmex, Hyogo, Japan). Neutrophils were suspended in Hanks' balanced salt solution. Total RNA extracted from PMN were obtained using the PureLink RNA Mini Kit (Ambion, Austin, TX). The DNase digestion was performed using Turbo DNA-free DNase (Ambion). Total RNA was quantified via spectrophotometry using a BioSpecnano (Shimadzu Corporation, Kyoto, Japan) and oligo (dt)18 Primer (Toyobo, Osaka, Japan). For each reaction, a parallel negative control reaction was performed in the absence of reverse transcriptase and analyzed by the $\beta$-actin band using PCR and $1.5 \%$ agarose gel stained with ethidium bromide, visualized on a UV transilluminator. For the standard curve, the amplified product of reverse-transcription PCR was cloned to the
pSTBlue-1 vector (Novagen, Madison, WI) and transformed into Escherichia coli DH5a (Takara, Shiga, Japan). The blue-white selection and PCR screening were conducted to identify the positive clones. The recombinant plasmid was purified using the GenElute Plasmid Miniprep Kit (Sigma) and gene sequencing. A standard curve for each gene was produced using 100- and 2-fold serial dilutions of the genes as a template $\left(10^{8}, 10^{6}\right.$, $10^{4}, 10^{2}$, and 50 copies). Information on the primers is shown in Table 1. We used the melting curve analysis to evaluate each primer pair for specificity to ascertain that only one product was amplified. We performed a Basic Local Alignment Search Tool search to confirm that the primer sequences amplified only the target gene of interest. The reaction was performed using a Thunderbird SYBR qPCR mix (Toyobo) and a MyiQicycler (Bio-Rad Laboratories, Hercules, CA). Thermal cycling consisted of initial denaturation at $95^{\circ} \mathrm{C}$ for 5 min, followed by 40 cycles of denaturation at $95^{\circ} \mathrm{C}$ for $15 \mathrm{~s}$, annealing at $60^{\circ} \mathrm{C}$ for $30 \mathrm{~s}$, and extension at $72^{\circ} \mathrm{C}$ for $30 \mathrm{~s}$. The melting temperature of the PCR product was determined by the melting curve analysis, which was performed by heating the PCR product from 55 to $95^{\circ} \mathrm{C}$ and monitoring the fluorescence change every $0.5^{\circ} \mathrm{C}$. We calculated the number of copies of each gene expressed in the bovine neutrophil using a standard curve. Beta-actin and tryptophan 5-monooxygenase activation protein zeta polypeptide ( $Y W H A Z$ ) were used as reference genes (Robinson et al., 2007; Spalenza et al., 2011).

\section{Statistical Analysis}

All data were analyzed using the Fit model procedure of JMP (version 13.2.1, SAS Institute Inc., Cary, NC). For variables not measured over time, such as apparent total-tract nutrient digestibility, the model included the fixed effects of dietary starch content, butyrate supplementation, their interaction, period, and parity, and the random effect of cow. For variables measured

Table 1. Sequences of oligonucleotide primers

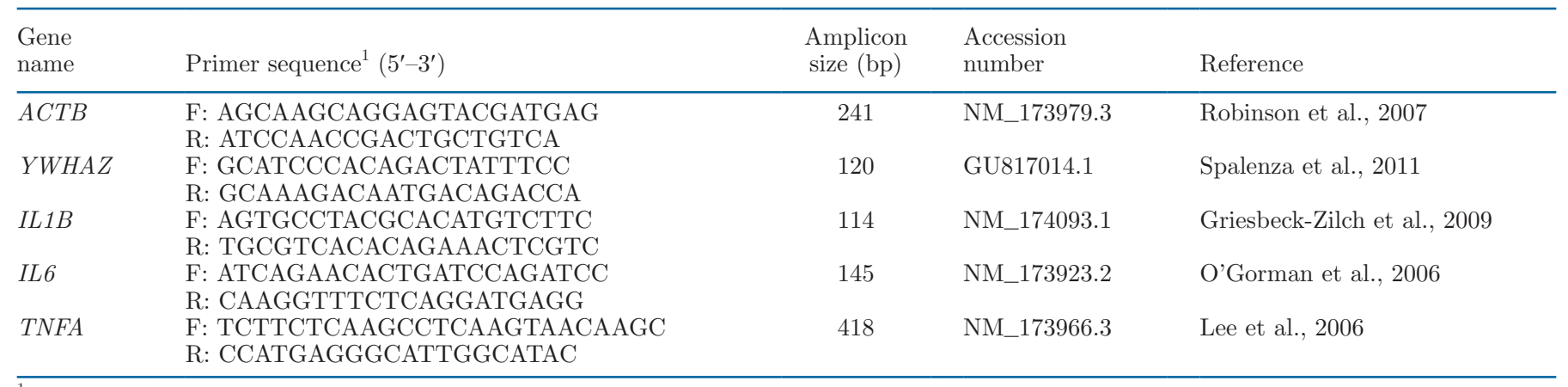

${ }^{1} \mathrm{~F}=$ forward; $\mathrm{R}=$ reverse. 
Table 2. Effects of the dietary starch content and the inclusion of butyrate on periprandial changes of rumen VFA profiles $\left(\right.$ LSM \pm SEM) ${ }^{1}$

\begin{tabular}{|c|c|c|c|c|c|c|c|c|c|}
\hline $\begin{array}{l}\text { Rumen VFA } \\
(\mathrm{m} M)\end{array}$ & \multicolumn{2}{|c|}{ LS } & \multicolumn{2}{|c|}{ HS } & SEM & \multicolumn{4}{|c|}{$P$-value } \\
\hline Total VFA & 106 & 104 & 101 & 99.8 & 5.17 & 0.299 & 0.727 & 0.956 & 0.006 \\
\hline Propionate & 20.5 & 19.1 & 21.4 & 19.3 & 1.55 & 0.625 & 0.105 & 0.725 & 0.020 \\
\hline n-Butyrate & 14.6 & 16.3 & 13.7 & 15.6 & 1.12 & 0.262 & 0.014 & 0.884 & $<0.001$ \\
\hline i-Butyrate & 0.62 & 0.42 & 0.29 & 0.38 & 0.098 & 0.078 & 0.587 & 0.164 & 0.029 \\
\hline
\end{tabular}

${ }^{1} \mathrm{LS}=$ low-starch diets; HS = high-starch diets; CON = control diet; butyrate = diet containing butyrate.

over time, such as serum and plasma measurements and mRNA abundance, the model included the fixed effects of dietary starch content, butyrate supplementation, collection time as a repeated measure, starch content and butyrate interaction, starch content and time interaction, butyrate and time interaction, and starch content, butyrate and time interaction, period, parity, and the random effect of cow nested in parity with compound symmetry as a covariant structure. For rumen measurements, the fixed effects of parity were excluded from the model. Differences were considered to be significant at $P<0.05$ and a tendency was declared at $P<0.10$.

\section{RESULTS}

\section{Rumen VFA and Plasma GLP-2 Concentration}

Ruminal concentrations of total VFA, acetate, and propionate were not affected by starch content or butyrate supplementation, but rumen n-butyrate concentration was higher for cows fed butyrate diets than cows fed control diets (16.0 vs. $14.2 \mathrm{mM}, P=0.014$; Table 2). Regardless of dietary treatment, plasma GLP-2 and rumen total VFA concentrations increased after feeding (time effects; $P<0.006$ ). The interaction between starch content and butyrate supplementation was detected for plasma GLP-2 concentration $(P=0.008$, Figure 1); plasma GLP-2 concentration was higher for cows fed HS diet with butyrate compared with those fed the other 3 treatment diets $(P<0.05)$.

\section{Apparent Total-Tract Nutrient Digestibility}

Interactions between starch content and butyrate supplementation were not detected for total-tract apparent digestibility (Table 3). Dry matter and OM digestibility tended to be higher for cows fed butyrate diets than those fed control diets $(P=0.073$, and $P$ $=0.083$, respectively), but starch, $\mathrm{NDF}$, and $\mathrm{CP}$ digestibilities were not affected by butyrate treatment. Starch, NDF, and CP digestibilities were lower for cows fed the HS diets than those fed LS diets $(P=0.005, P$ $<0.001$, and $P=0.020$, respectively).

\section{Responses to Grain Challenge}

Due to equipment failure, we could not collect sufficient rumen $\mathrm{pH}$ data to evaluate treatment effects. However, we determined effects of grain challenge on rumen $\mathrm{pH}$ (before grain challenge vs. during the grain challenge; mean of d 17 to 19 vs. d 21), and found that daily mean (6.36 vs. $6.23, P=0.256)$, nadir rumen $\mathrm{pH}$ (5.51 vs. $5.39, P=0.333)$, and area under the curve $<$ pH 5.8 (29.6 vs. $67.2 \mathrm{pH}$ units $\times \min / \mathrm{d}, P=0.214$ ) were not different between the sampling period before grain challenge and during grain challenge.

Regardless of treatment, ruminal endotoxin concentration was higher $24 \mathrm{~h}$ after the grain challenge compared with 0 and $6 \mathrm{~h}(P<0.05$, Figure $2 \mathrm{~A})$, and

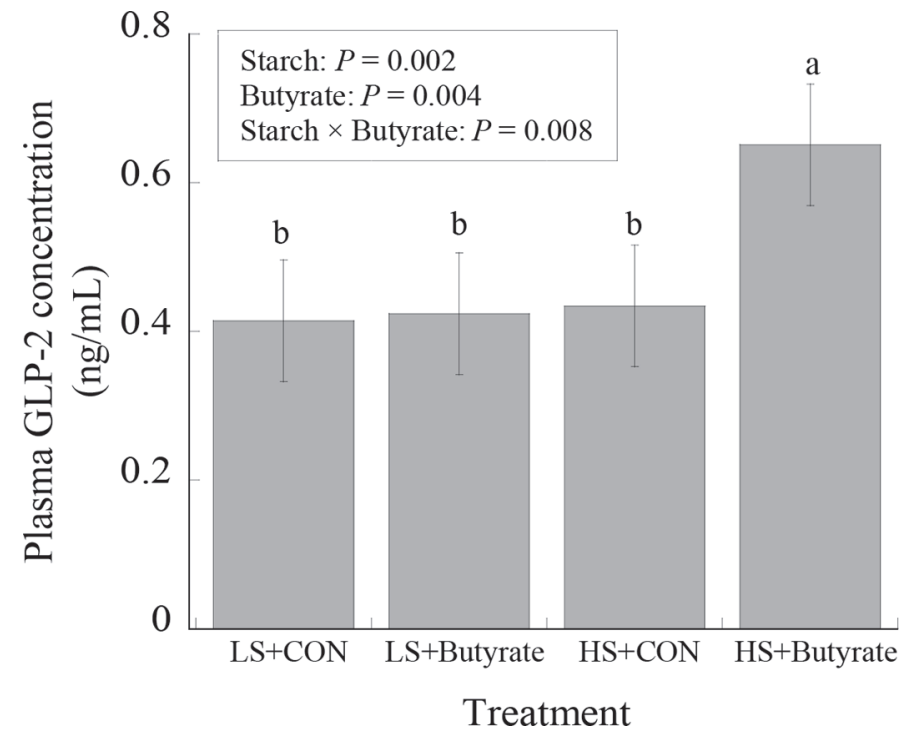

Figure 1. Least squares means and SEM $(\mathrm{n}=8)$ for plasma glucagon-like peptide-2 (GLP-2) concentration by cows fed low-starch (LS) + control $(\mathrm{CON}), \mathrm{LS}+$ butyrate, high-starch $(\mathrm{HS})+\mathrm{CON}$, and $\mathrm{HS}+$ butyrate diets. Means with different letters $(\mathrm{a}, \mathrm{b})$ are different among treatments $(P<0.05)$. 
higher for cows fed the HS diets $(P=0.028$, Figure $3 \mathrm{~A})$. However, time effects were not observed for plasma endotoxin, and serum LBP, TNF-a, SAA, and Hp $(P \geq 0.450$, Figure $2 \mathrm{~B}-\mathrm{F})$. Interactions between starch content and butyrate supplementation were detected for plasma endotoxin $(P=0.018$, Figure $3 \mathrm{~B})$ and $\mathrm{Hp}$ $(P=0.023$, Figure $3 \mathrm{~F})$, and interaction tendencies were observed for $\operatorname{LBP}(P=0.092$, Figure $3 \mathrm{C})$ and SAA $(P=0.070$, Figure $3 \mathrm{E})$. Butyrate supplementation increased plasma endotoxin, serum LBP, SAA, and Hp concentrations for cows fed the LS diet, but did not for cows fed the HS diet. Gene expression of proinflammatory cytokines of neutrophil in the peripheral blood was not affected by dietary treatments (Figure 4).

\section{DISCUSSION}

In the present study, we observed that butyrate supplementation increased plasma GLP-2 concentration when cows were fed the HS diet, but did not when they were fed the LS diet. The stimulatory effect of VFA, especially butyrate, on GLP-2 secretions has been well documented in previous research (Tappenden et al., 2003; Yadav et al., 2013). In sheep, intraruminal administration of sodium butyrate and VFA mixture increased plasma GLP-2 concentration (Elsabagh et al., 2017). In mid-lactating dairy cows fed a 50:50 roughage: concentrate diet, the portal-derived visceral flux of butyrate and BHB was $12 \mathrm{~mol} / \mathrm{d}$ (Benson et al., 2002), suggesting that the cows produce approximately $1 \mathrm{~kg} / \mathrm{d}$ of butyrate from fermentation of feeds in the rumen. In the present study, the amount of butyrate supplementation was equivalent to approximately $25 \%$ of butyrate derived from ruminal fermentation. However, this dosage might not be high enough to increase plasma GLP-2 concentration in the LS diet, although butyrate supplementation increased ruminal butyrate concentration regardless of dietary starch content. Although ruminal butyrate concentration was not dif- ferent between LS and HS diets, butyrate supplementation increased plasma GLP-2 concentration only when fed in the HS diet, suggesting that butyrate concentration in the ruminal fluid per se may not affect plasma GLP-2 concentration. A possible explanation for the positive effect of butyrate with the HS diet on plasma GLP-2 concentration is that the butyrate flow to the lower gut might have increased due to tendency for greater DMI (Izumi et al., 2019) as greater DMI can increase passage rate of digesta from the rumen (Djouvinov and Todorov, 1994). Górka et al. (2017) showed that duodenal butyrate flow increased as the butyrate dose increased, suggesting that ingested butyrate partly escapes the ruminal absorption and reaches the lower gut. The amount of butyrate flow to the lower gut is expected to vary depending on the passage rate of digesta as well as the dosage amount of butyrate. In addition, butyrate produced from hindgut fermentation might have stimulated GLP-2 secretion (Tappenden et al., 2003). Based on these findings, we speculated that butyrate supplementation in cows fed the HS diet likely increased butyrate flow to the lower gut, resulting in the higher plasma GLP-2 concentration through the direct stimulation of the $\mathrm{L}$ cell.

We observed that butyrate supplementation tended to increase DM and OM digestibility. In the study of Huhtanen et al. (1993), total-tract digestibilities of DM, $\mathrm{OM}, \mathrm{CP}$, and NDF in lactating cows increased linearly with the infusion rate of butyrate increased. Butyrate supplementation might have increased nutrient digestibility through alterations of the gastrointestinal function; intraruminal infusion or intake of butyrate accelerated ruminal epithelium growth and increased ruminal papilla length (Sakata and Tamate, 1978; Mentschel et al., 2001), ruminal epithelial blood flow, and VFA absorption (Storm et al., 2011). In addition, Guilloteau et al. (2010) reported that butyrate supplementation stimulated digestive enzyme secretions. In the study by Deng et al. (2016), exogenous GLP-2 increased diges-

Table 3. Effects of the dietary starch content and the inclusion of butyrate on DMI and apparent total-tract nutrient digestibility (LSM \pm SEM $)^{1}$

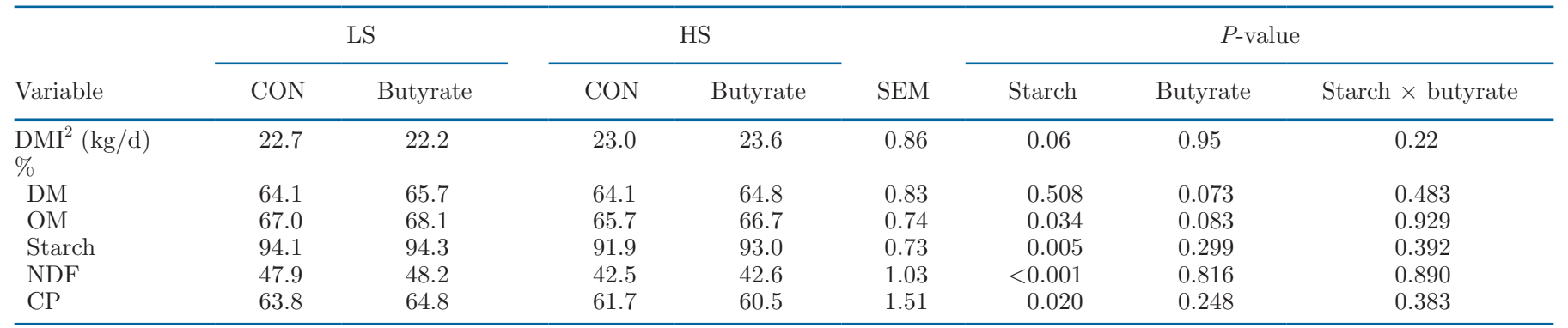

${ }^{1} \mathrm{LS}=$ low-starch diets; HS = high-starch diets; $\mathrm{CON}=$ control diet; butyrate = diet containing butyrate.

${ }^{2}$ From Izumi et al. (2019). 
A

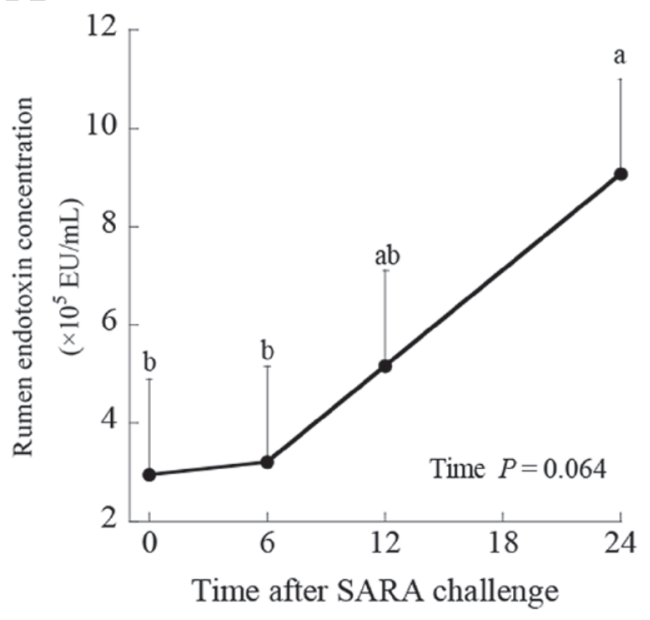

$\mathrm{C}$

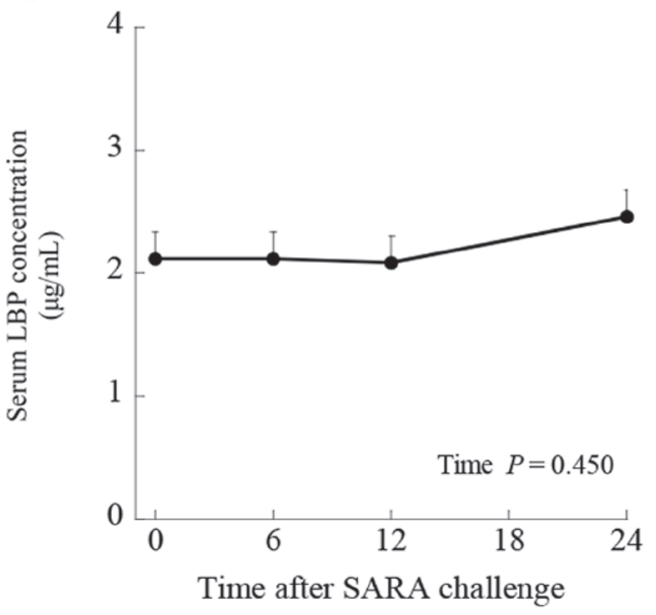

E

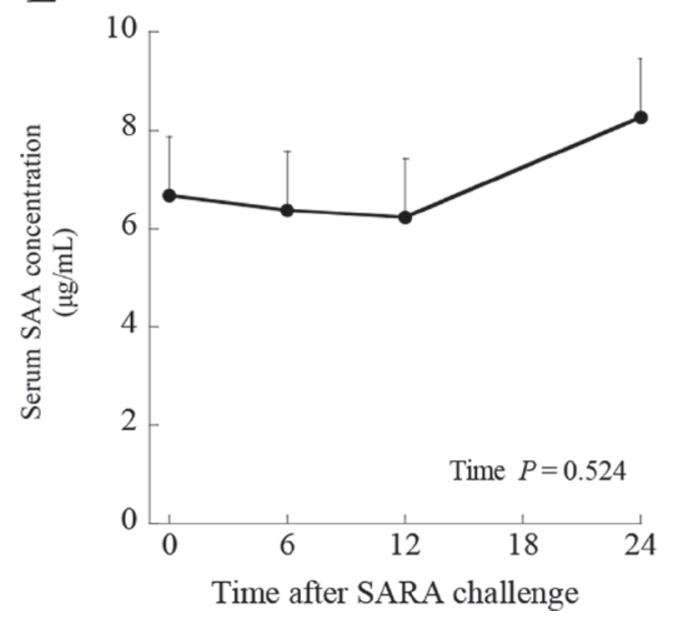

B

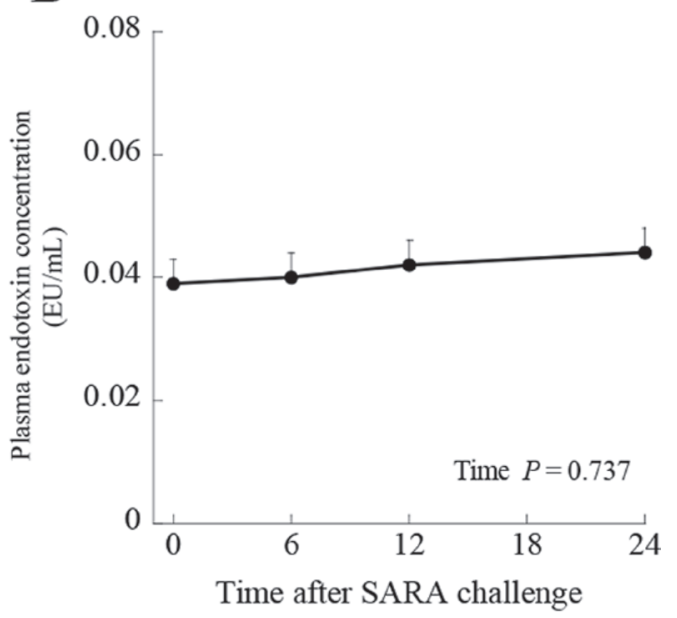

D

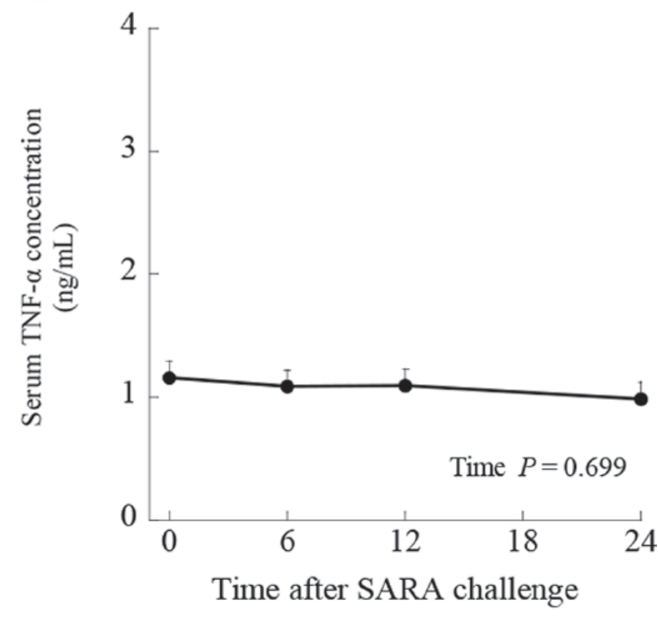

F

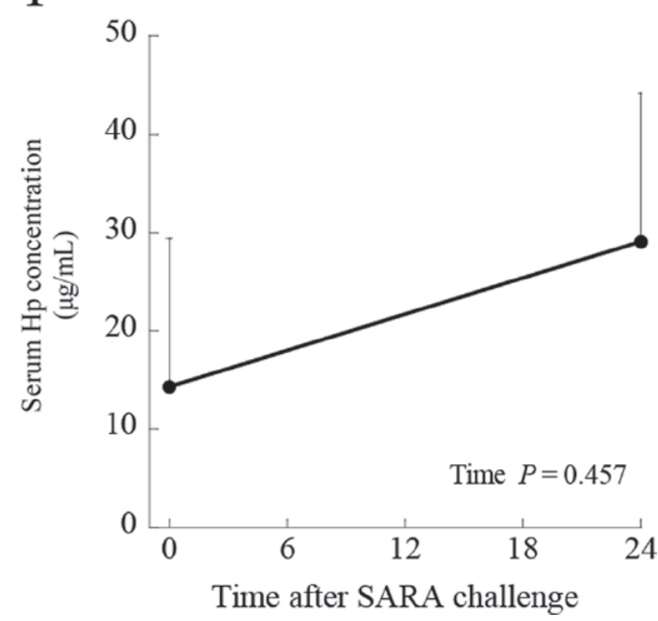

Figure 2. Least squares means and SEM for rumen endotoxin concentration $(\mathrm{A} ; \mathrm{n}=4)$, plasma endotoxin $(\mathrm{B})$, serum lipopolysaccharidebinding protein $(\mathrm{LBP} ; \mathrm{C})$, tumor necrosis factor- $\alpha(\mathrm{TNF}-\alpha ; \mathrm{D})$, serum amyloid A (SAA; E), and haptoglobin $($ Hp; $\mathrm{F})$ concentrations $(\mathrm{n}=8)$ before $(0 \mathrm{~h})$, and 6,12 , and $24 \mathrm{~h}$ after the grain challenge. Student's $t$-test was conducted if $P<0.10$ for time effect. Means with different letters $(\mathrm{a}, \mathrm{b})$ are different among the sampling times $(P<0.05)$. EU $=$ endotoxin units. 
A

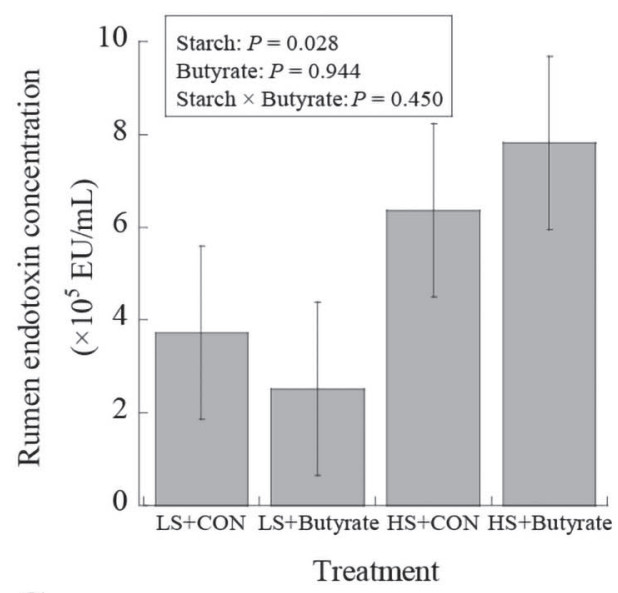

C

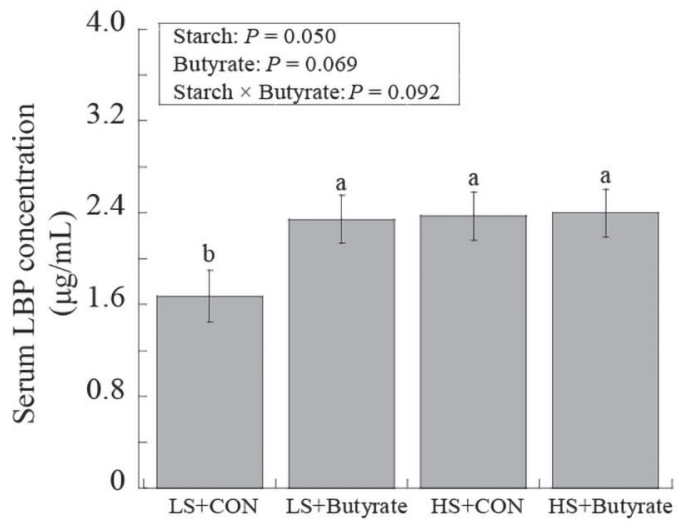

Treatment

E

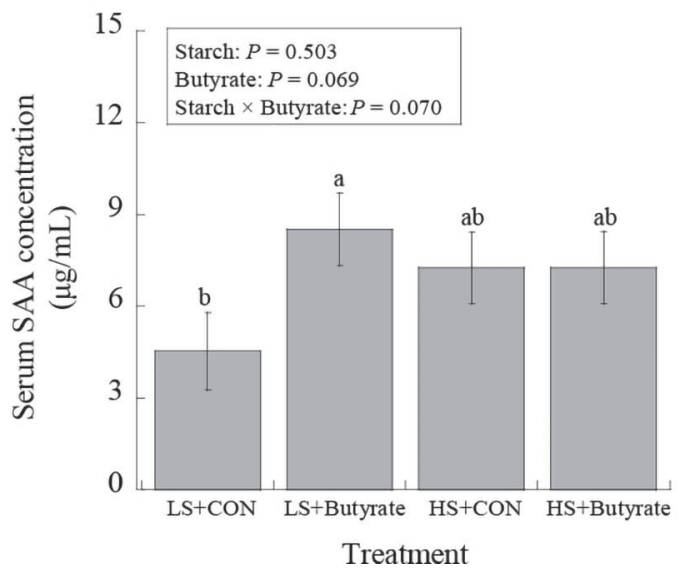

B

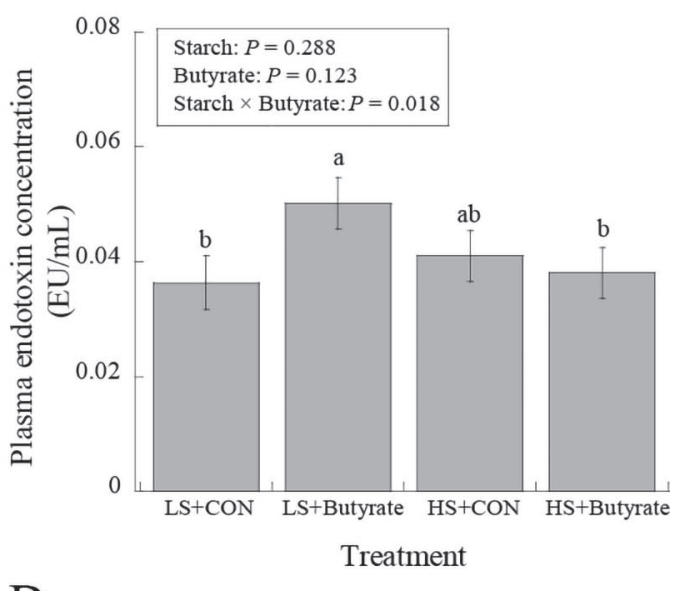

D
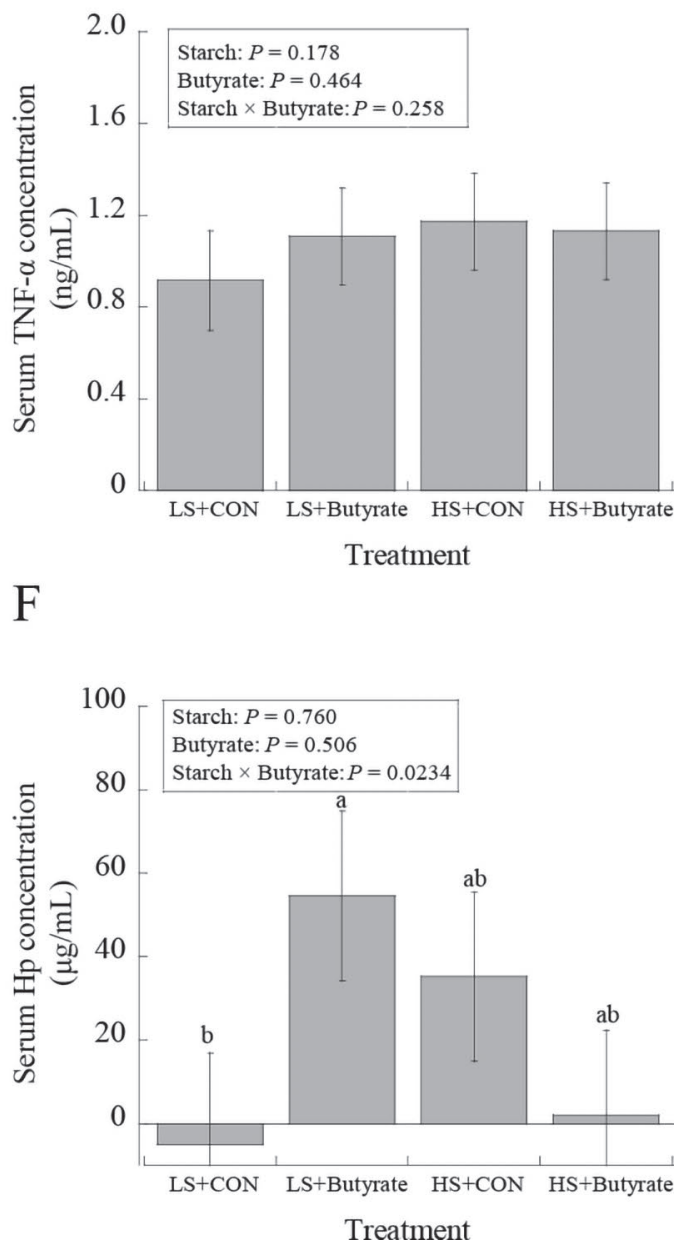

Figure 3. Least squares means and SEM for rumen endotoxin concentration $(\mathrm{A} ; \mathrm{n}=4)$, plasma endotoxin (B), serum lipopolysaccharidebinding protein (LBP; C), tumor necrosis factor- $\alpha(\mathrm{TNF}-\alpha ; \mathrm{D})$, serum amyloid A (SAA; E), and haptoglobin $(\mathrm{Hp} ; \mathrm{F})$ concentrations $(\mathrm{n}=8)$ by cows fed low-starch (LS) + control $(\mathrm{CON}), \mathrm{LS}+$ butyrate, high-starch $(\mathrm{HS})+\mathrm{CON}$, and HS + butyrate diets during the grain challenge. Student's $t$-test was conducted if $P<0.10$ for interactions of main effects. Means with different letters $(\mathrm{a}, \mathrm{b})$ are different among treatments $(P<0.05)$. 
tive enzyme activity in the small intestine. In the present study, plasma GLP-2 concentration increased only in cows fed butyrate in the HS diet, but the tendency of a positive effect of GLP-2 on nutrient digestibility was observed regardless of dietary starch content, as such GLP-2 may not mediate the tendency of positive effects of butyrate on apparent total-tract digestibility in this study. Nonetheless, digestibility data in the present study should be interpreted with caution as positive effects of butyrate supplementation were not detected for starch, NDF, and CP digestibilities, indicating that digestibility of a non-starch NFC fraction likely increased. The greater digestibility of non-starch NFC fraction between butyrate and control treatments may be simply due to the replacement of wheat bran with sodium butyrate, reflecting grater disappearance of butyrate compared with wheat bran.

A

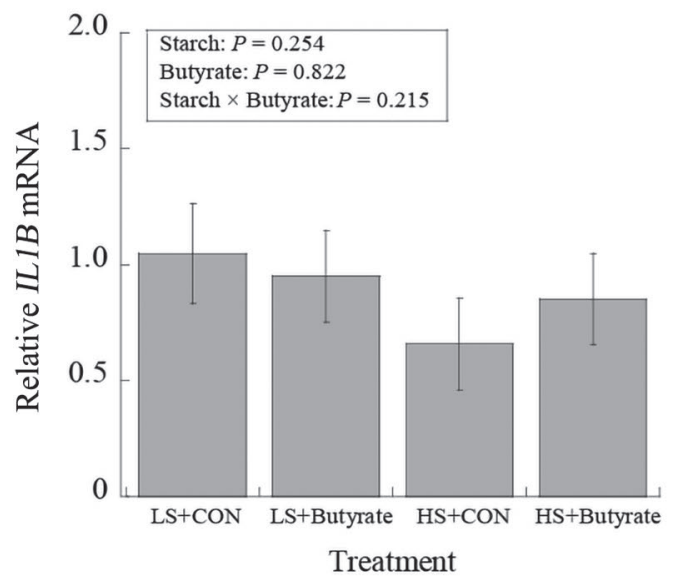

C

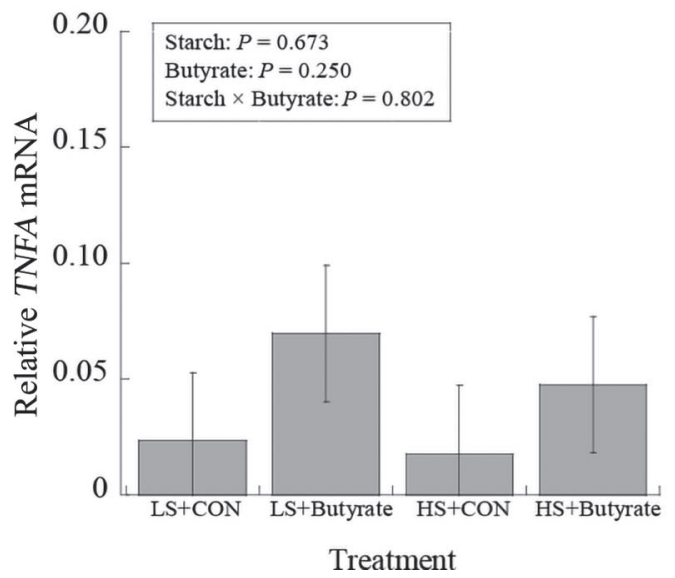

In the present study, we intended to determine if feeding butyrate could mitigate inflammatory responses induced by high grain diets because butyrate or GLP-2 can promote epithelial integrity and barrier function, resulting in the prevention of endotoxin translocation into the blood circulation and local immune responses in the mucosa (Connor et al., 2013; Kvidera et al., 2017; Górka et al., 2018). As an experimental method, we conducted a grain challenge, which previously reported to increase blood pro-inflammatory cytokines and acute phase proteins (APP) in ruminants (Khafipour et al., 2009; González et al., 2010). However, we found that plasma endotoxin and serum APP concentrations did not increase after the grain challenge although ruminal endotoxin concentration increased, indicating that elevated ruminal endotoxin concentration was not associated with systemic inflammatory responses

B

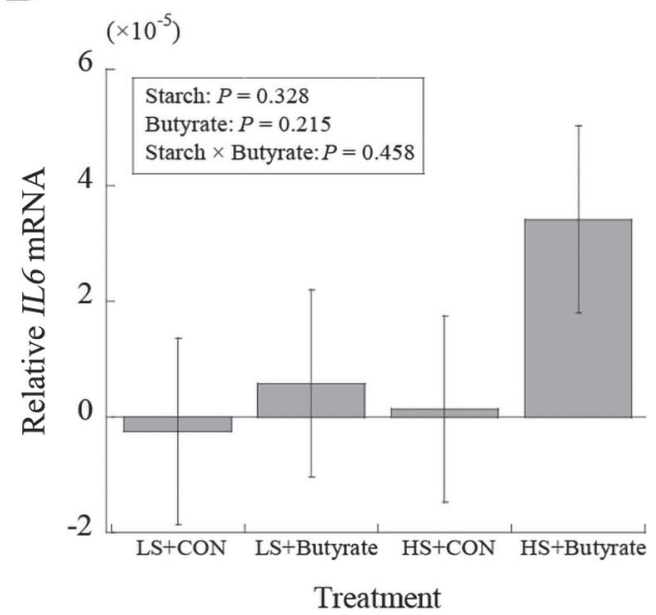


in the current study. However, it is noteworthy that butyrate supplementation increased concentrations of plasma endotoxin, and serum LBP, SAA, and Hp concentrations for cows fed the LS diet, but not for cows fed the HS diet. In the present study, any differences in pro-inflammatory cytokine mRNA expressions of peripheral circulating neutrophils were not detected, indicating that the endotoxin entry into the blood, if any, was too little to induce systemic inflammation. Therefore, greater APP for cows fed butyrate with the LS diet might not be mediated by systemic reaction, but by local inflammatory responses released from gut epithelium and neutrophils around the gastrointestinal tract (Zhao et al., 2018). Several receptors that recognize endotoxins, such as toll-like receptor (TLR) 2 and TLR4, are localized in the rumen epithelium (Chen et al., 2012) and the intestinal epithelium (Villena et al., 2014), and these receptors may increase serum APP concentration via local luminal inflammation (Zhang et al., 2016). Chen et al. (2012) reported that gene expression of TLR4 in the rumen epithelium was higher in cattle with SARA. The inflammatory effects of butyrate are reported by several studies. In the studies of colonic adenocarcinoma cell line cultures, butyrate treatment increased epithelial expression of TLR4, mitogen-activated protein kinase, and nuclear factor$\kappa \mathrm{B}$ signal pathway activation and pro-inflammatory response (Andoh et al., 1999; Hýzd'alová et al., 2008; Xiao et al., 2018).

Elevation of plasma BHB concentration might be another possible reason that butyrate supplementation in the LS diet increased serum APP concentrations. In a previous study where dairy cows received intravenous BHB infusion (Zarrin et al., 2014), elevated serum BHB concentration (constantly kept around $1.7 \mathrm{mM}$ ) augmented the increase of APP in the mammary gland during the intramammary LPS challenge. In the present study, butyrate supplementation and LS diets increased serum BHB concentration compared with control and HS diets, respectively (Izumi et al., 2019), and butyrate with the LS diet might have stimulated inflammatory responses by elevated circulating BHB concentration.

However, serum APP concentrations did not increase in cows fed HS + butyrate diet. This is likely because higher GLP-2 concentration, observed only for this dietary treatment, might have reduced inflammatory responses. The effect of GLP-2 on the intestinal inflammation has been examined in animal models and in vitro studies. In a rat model of inflammatory bowel disease, rats treated with GLP-2 showed reduced incidence of mucosal damage, inflammatory infiltrate, and submucosal edema compared with the control (Alavi et al., 2000). In the weaning piglets, exogenous GLP-2 treatment protected against the intestinal damage in- duced by intraperitoneal LPS challenge (Deng et al., 2016) through the downregulation of IL- $8, \mathrm{TNF}-\alpha$, and interferon-gamma mRNA in the duodenum (Wu et al., 2016). In addition, GLP-2 was found to suppress the increases in expression of TNF- and interferon-associated inflammation in the small intestine, colon (Boushey et al., 1999; Drucker et al., 1999), and peritoneal macrophages (Xie et al., 2014), suggesting that GLP-2 has direct anti-inflammatory actions in the gastrointestinal tract. For these reasons, butyrate itself might have acted as a factor to induce inflammation by the enhancement of LPS responsiveness on the epithelium, but GLP-2 might have anti-inflammatory actions by mitigating LPS-related signal pathway.

\section{CONCLUSIONS}

Butyrate supplementation in a HS diet increased plasma GLP-2 concentration in lactating dairy cows. Feeding butyrate tended to increase apparent totaltract $\mathrm{DM}$ and $\mathrm{OM}$ digestibility regardless of dietary starch content. However, anti-inflammatory actions of butyrate were not observed in this study.

\section{ACKNOWLEDGMENTS}

The authors thank students of Ruminology and Herd Health units at Rakuno Gakuen University and staff of Rakuno Gakuen Field Education and Research Center for their technical assistance. This work was financially supported by Rakuno Gakuen University Research Fund (\#2018-03; Ebetsu, Japan), Japan Society for the Promotion of Science (\#18K1493, \#L18535; Tokyo, Japan), and Natural Sciences and Engineering Research Council of Canada (Ottawa, ON, Canada). We gratefully acknowledge YPTECH Co. Ltd. (Tokyo, Japan) for donation of GUSTOR BP70, and Masakazu Tsuchiya, a senior research scientist at Charles River Laboratories Inc. (Charleston, SC) for provision of the analytical reagents and technical advice for endotoxin assay. The authors have not stated any conflicts of interest.

\section{REFERENCES}

Alavi, K., M. Z. Schwartz, J. P. Palazzo, and R. Prasad. 2000. Treatment of inflammatory bowel disease in a rodent model with the intestinal growth factor glucagon-like peptide-2. J. Pediatr. Surg. 35:847-851. https://doi.org/10.1053/jpsu.2000.6861.

Andoh, A., Y. Fujiyama, K. Hata, A. Araki, H. Takaya, M. Shimada, and T. Bamba. 1999. Counter-regulatory effect of sodium butyrate on tumour necrosis factor-alpha (TNF-alpha)-induced complement C3 and factor B biosynthesis in human intestinal epithelial cells. Clin. Exp. Immunol. 118:23-29. https://doi.org/10.1046/j.1365 -2249.1999.01038.x.

AOAC International. 2000. Official Methods of Analysis. 17th ed. AOAC Int., Gaithersburg, MD. 
Araujo, G., M. Terre, A. Mereu, I. R. Ipharraguerre, and A. Bach. 2016. Effects of supplementing a milk replacer with sodium butyrate or tributyrin on performance and metabolism of Holstein calves. Anim. Prod. Sci. 56:1834-1841. https://doi.org/10.1071/ AN14930.

Benjamin, M. A., D. M. McKay, P. C. Yang, H. Cameron, and M. H. Perdue. 2000. Glucagon-like peptide-2 enhances intestinal epithelial barrier function of both transcellular and paracellular pathways in the mouse. Gut 47:112-119. https://doi.org/10.1136/gut .47.1.112

Benson, J. A., C. K. Reynolds, P. C. Aikman, B. Lupoli, and D. E. Beever. 2002. Effects of abomasal vegetable oil infusion on splanchnic nutrient metabolism in lactating dairy cows. J. Dairy Sci. 85:1804-1814. https://doi.org/10.3168/jds.S0022-0302(02)74255 -0 .

Boushey, R. P., B. Yusta, and D. J. Drucker. 1999. Glucagon-like peptide 2 decreases mortality and reduces the severity of indomethacin-induced murine enteritis. Am. J. Physiol. 277:E937-E947. https://doi.org/10.1152/ajpendo.1999.277.5.E937.

Burrin, D. G., B. Stoll, and X. Guan. 2003. Glucagon-like peptide 2 function in domestic animals. Domest. Anim. Endocrinol. 24:103122. https://doi.org/10.1016/S0739-7240(02)00210-2.

Chen, Y., M. Oba, and L. L. Guan. 2012. Variation of bacterial communities and expression of Toll-like receptor genes in the rumen of steers differing in susceptibility to subacute ruminal acidosis. Vet. Microbiol. 159:451-459. https://doi.org/10.1016/j.vetmic.2012.04 .032 .

Christensen, M., S. Jacobsen, T. Ichiyanagi, and M. Kjelgaard-Hansen. 2012. Evaluation of an automated assay based on monoclonal anti-human serum amyloid A (SAA) antibodies for measurement of canine, feline, and equine SAA. Vet. J. 194:332-337. https://doi .org/10.1016/j.tvjl.2012.05.007.

Cochran, R. C., D. C. Adams, J. D. Wallace, and M. L. Galyean. 1986. Predicting digestibility of different diets with internal markers: Evaluation of four potential markers. J. Anim. Sci. 63:1476-1483. https://doi.org/10.2527/jas1986.6351476x.

Connor, E. E., S. Kahl, T. H. Elsasser, R. L. Baldwin VI, R. Fayer, M. Santin-Duran, G. L. Sample, and C. M. Evock-Clover. 2013. Glucagon-like peptide 2 therapy reduces negative effects of diarrhea on calf gut. J. Dairy Sci. 96:1793-1802. https://doi.org/10 $.3168 / \mathrm{jds} .2012-6216$.

Cooper, J. F., K. S. Latta, and D. Smith. 2010. Automated endotoxin testing program for high-risk-level compounded sterile preparations at an institutional compounding pharmacy. Am. J. Health Syst. Pharm. 67:280-286. https://doi.org/10.2146/ajhp090290.

Deng, Q. H., G. Jia, H. Zhao, Z. L. Chen, X. L. Chen, G. M. Liu, and K. N. Wang. 2016. The prolonged effect of glucagon-like peptide 2 pretreatment on growth performance and intestinal development of weaned piglets. J. Anim. Sci. Biotechnol. 7:28. https://doi.org/ 10.1186/s40104-016-0087-7.

Djouvinov, D. S., and N. A. Todorov. 1994. Influence of dry matter intake and passage rate on microbial protein synthesis in the rumen of sheep and its estimation by cannulation and a non-invasive method. Anim. Feed Sci. Technol. 48:289-304. https://doi.org/10 .1016/0377-8401(94)90179-1.

Drucker, D. J., B. Yusta, R. P. Boushey, L. DeForest, and P. L. Brubaker. 1999. Human $\left[\mathrm{Gly}^{2}\right]$ GLP-2 reduces the severity of colonic injury in a murine model of experimental colitis. Am. J. Physiol. 276:G79-G91. https://doi.org/10.1152/ajpgi.1999.276.1 G79.

Eckel, E. F., and B. N. Ametaj. 2016. Invited review: Role of bacterial endotoxins in the etiopathologenesis of periparturient diseases of transition dairy cows. J. Dairy Sci. 99:5967-5990. https://doi.org/ $10.3168 /$ jds. $2015-10727$.

Elsabagh, M., Y. Inabu, T. Obitsu, and T. Sugino. 2017. Response of plasma glucagon-like peptide-2 to feeding pattern and intraruminal administration of volatile fatty acids in sheep. Domest. Anim. Endocrinol. 60:31-41. https://doi.org/10.1016/j.domaniend.2017 .03 .001 .

Emmanuel, D. G., K. L. Madsen, T. A. Churchill, S. M. Dunn, and B. N. Ametaj. 2007. Acidosis and lipopolysaccharide from Esch- erichia coli B:055 cause hyperpermeability of rumen and colon tissues. J. Dairy Sci. 90:5552-5557. https://doi.org/10.3168/jds .2007-0257.

Fukumori, N. T., D. G. de Campos, A. V. Massicano, N. P. de Pereira, C. P. da Silva, and M. M. Matsuda. 2011. A portable test system for determination of bacterial endotoxins in 18F-FDG, 99mTc, and lyophilized reagents for labeling with $99 \mathrm{mTc}$. J. Nucl. Med. Technol. 39:121-124. https://doi.org/10.2967/jnmt.110.081380.

Gee, A. P., D. Sumstad, J. Stanson, P. Watson, J. Proctor, D. Kadidlo, E. Koch, J. Sprague, D. Wood, D. Styers, D. McKenna, J. Gallelli, D. Griffin, E. J. Read, B. Parish, and R. Lindblad. 2008. A multicenter comparison study between the Endosafe PTS rapid-release testing system and traditional methods for detecting endotoxin in cell-therapy products. Cytotherapy 10:427-435. https://doi.org/10 $.1080 / 14653240802075476$.

González, F. H. D., F. H. Ruipérez, J. M. Sánchez, J. C. Souza, S. Martínez-Subiela, and J. J. Cerón. 2010. Haptoglobin and serum amyloid A in subacute ruminal acidosis in goats. Rev. Med. Vet. Zoot. 57:159-167.

Górka, P., Z. M. Kowalski, P. Pietrzak, A. Kotunia, W. Jagusiak, J. J. Holst, R. Guilloteau, and R. Zabielski. 2011a. Effect of method of delivery of sodium butyrate on rumen development in newborn calves. J. Dairy Sci. 94:5578-5588. https://doi.org/10.3168/jds 2011-4166.

Górka, P., Z. M. Kowalski, P. Pietrzak, A. Kotunia, W. Jagusiak, and R. Zabielski. 2011b. Is rumen development in newborn calves affected by different liquid feeds and small intestine development? J. Dairy Sci. 94:3002-3013. https://doi.org/10.3168/jds.2010-3499.

Górka, P., Z. M. Kowalski, R. Zabielski, and P. Guilloteau. 2018. Invited review: Use of butyrate to promote gastrointestinal tract development in calves. J. Dairy Sci. 101:4785-4800. https://doi .org/10.3168/jds.2017-14086.

Górka, P., B. Śliwiński, J. Flaga, J. Wieczorek, M. M. Godlewski, E. Wierzchoś, R. Zabielski, and Z. M. Kowalski. 2017. Effect of butyrate infusion into the rumen on butyrate flow to the duodenum, selected gene expression in the duodenum epithelium, and nutrient digestion in sheep. J. Anim. Sci. 95:2144-2155.

Griesbeck-Zilch, B., M. Osman, C. Kühn, M. Schwerin, R. H. Bruckmaier, M. W. Pfaffl, A. Hammerle-Fickinger, H. H. Meyer, and O. Wellnitz. 2009. Analysis of key molecules of the innate immune system in mammary epithelial cells isolated from marker-assisted and conventionally selected cattle. J. Dairy Sci. 92:4621-4633. https://doi.org/10.3168/jds.2008-1954.

Guilloteau, P., G. Savary, Y. Jaguelin-Peyrault, V. Rome, L. Le Normand, and R. Zabielski. 2010. Dietary sodium butyrate supplementation increases digestibility and pancreatic secretion in young milk-fed calves. J. Dairy Sci. 93:5842-5850. https://doi.org/10 .3168/jds.2009-2751.

Guilloteau, P., R. Zabielski, J. C. David, J. W. Blum, J. A. Morisset, M. Biernat, J. Woliński, D. Laubitz, and Y. Hamon. 2009. Sodium-butyrate as a growth promoter in milk replacer formula for young calves. J. Dairy Sci. 92:1038-1049. https://doi.org/10 $.3168 /$ jds.2008-1213.

Hadjiyanni, I., K. K. Li, and D. J. Drucker. 2009. Glucagon-like peptide-2 reduces intestinal permeability but does not modify the onset of type 1 diabetes in the nonobese diabetic mouse. Endocrinology 150:592-599. https://doi.org/10.1210/en.2008-1228.

Hall, M. B. 2009. Analysis of starch, including malt oligosaccharides, in animal feeds: A comparison of methods and a recommended method for AOAC collaborative study. J. AOAC Int. 92:42-49.

Huhtanen, P., K. Kaustell, and S. Jaakkola. 1994. The use of internal markers to predict total digestibility and duodenal flow of nutrients in cattle given six different diets. Anim. Feed Sci. Technol. 48:211-227. https://doi.org/10.1016/0377-8401(94)90173-2.

Huhtanen, P., H. Miettinen, and M. Ylinen. 1993. Effect of increasing ruminal butyrate on milk yield and blood constituents in dairy cows fed a grass silage-based diet. J. Dairy Sci. 76:1114-1124 https://doi.org/10.3168/jds.S0022-0302(93)77440-8.

Hýžd'alová, M., J. Hofmanová, J. Pacherník, A. Vaculová, and A. Kozubík. 2008. The interaction of butyrate with TNF-alpha during differentiation and apoptosis of colon epithelial cells: Role of NF- 
kappaB activation. Cytokine 44:33-43. https://doi.org/10.1016/j cyto.2008.06.003.

Inabu, Y., K. Murayama, K. Inouchi, and T. Sugino. 2019. The effect of tributyrin supplementation to milk replacer on plasma glucagon-like peptide 2 concentrations in pre-weaning calves. Anim. Sci. J. 90:1185-1192. https://doi.org/10.1111/asj.13262.

Izumi, K., R. Fukumori, S. Oikawa, and M. Oba. 2019. Short communication: Effects of butyrate supplementation on productivity of lactating dairy cows fed diets differing in starch content. J. Dairy Sci. 102:11051-11056. https://doi.org/10.3168/jds.2019-17113.

Jimenez, L., N. Rana, K. Travers, V. Tolomanoska, and K. Walker. 2010. Evaluation of the Endosafe ${ }^{\circledR}$ portable testing system for the rapid analysis of biopharmaceutical samples. PDA J. Pharm. Sci. Technol. 64:211-221.

Khafipour, E., D. O. Krause, and J. C. Plaizier. 2009. A grain-based subacute ruminal acidosis challenge causes translocation of lipopolysaccharide and triggers inflammation. J. Dairy Sci. 92:10601070. https://doi.org/10.3168/jds.2008-1389.

Kurashima, Y., Y. Goto, and H. Kiyono. 2013. Mucosal innate immune cells regulate both gut homeostasis and intestinal inflammation. Eur. J. Immunol. 43:3108-3115. https://doi.org/10.1002/ eji.201343782.

Kvidera, S. K., E. A. Horst, M. V. Sanz Fernandez, M. Abuajamieh, S. Ganesan, P. J. Gorden, H. B. Green, K. M. Schoenberg, W. E. Trout, A. F. Keating, and L. H. Baumgard. 2017. Characterizing effects of feed restriction and glucagon-like peptide 2 administration on biomarkers of inflammation and intestinal morphology. J. Dairy Sci. 100:9402-9417. https://doi.org/10.3168/jds.2017-13229.

Lee, J. W., D. D. Bannerman, M. J. Paape, M. K. Huang, and X. Zhao. 2006. Characterization of cytokine expression in milk somatic cells during intramammary infections with Escherichia coli or Staphylococcus aureus by real-time PCR. Vet. Res. 37:219-229. https://doi.org/10.1051/vetres:2005051.

Mentschel, J., R. Leiser, C. Mulling, C. Pfarrer, and R. Claus. 2001. Butyric acid stimulates rumen mucosa development in the calf mainly by a reduction of apoptosis. Arch. Anim. Nutr. 55:85-102.

O'Gorman, G. M., S. D. Park, E. W. Hill, K. G. Meade, L. C. Mitchell, M. Agaba, J. P. Gibson, O. Hanotte, J. Naessens, S. J. Kemp, and D. E. MacHugh. 2006. Cytokine mRNA profiling of peripheral blood mononuclear cells from trypanotolerant and trypanosusceptible cattle infected with Trypanosoma congolense. Physiol. Genomics 28:53-61. https://doi.org/10.1152/physiolgenomics.00100 2006 .

Penner, G. B., K. A. Beauchemin, and T. Mutsvangwa. 2006. An evaluation of the accuracy and precision of a stand-alone submersible continuous ruminal $\mathrm{pH}$ measurement system. J. Dairy Sci. 89:2132-2140. https://doi.org/10.3168/jds.S0022-0302(06)72284 $-6$.

Penner, G. B., K. A. Beauchemin, and T. Mutsvangwa. 2007. Severity of ruminal acidosis in primiparous Holstein cows during the periparturient period. J. Dairy Sci. 90:365-375. https://doi.org/10 .3168/jds.S0022-0302(07)72638-3.

Robinson, T. L., I. A. Sutherland, and J. Sutherland. 2007. Validation of candidate bovine reference genes for use with real-time PCR. Vet. Immunol. Immunopathol. 115:160-165. https://doi.org/10 .1016/j.vetimm.2006.09.012.

Sakata, T., and H. Tamate. 1978. Rumen epithelial cell proliferation accelerated by rapid increase in intraruminal butyrate. J. Dairy Sci. 61:1109-1113. https://doi.org/10.3168/jds.S0022 -0302(78)83694-7.

Spalenza, V., F. Girolami, C. Bevilacqua, F. Riondato, R. Rasero, C. Nebbia, P. Sacchi, and P. Martin. 2011. Identification of internal control genes for quantitative expression analysis by real-time PCR in bovine peripheral lymphocytes. Vet. J. 189:278-283. https: //doi.org/10.1016/j.tvjl.2010.11.017.
Storm, A. C., M. D. Hanigan, and N. B. Kristensen. 2011. Effects of ruminal ammonia and butyrate concentrations on reticuloruminal epithelial blood flow and volatile fatty acid absorption kinetics under washed reticulorumen conditions in lactating dairy cows. J. Dairy Sci. 94:3980-3994. https://doi.org/10.3168/jds.2010-4091.

Suzuki, K., T. Shimamori, A. Sato, K. Tsukano, M. Tsuchiya, and J. Lakritz. 2015. Detecting endotoxin activity in bovine serum using an automated testing system. J. Vet. Med. Sci. 77:977-979. https: //doi.org/10.1292/jvms.14-0545.

Tappenden, K. A., D. M. Albin, A. L. Bartholome, and H. F. Mangian. 2003. Glucagon-like peptide-2 and short-chain fatty acids: A new twist to an old story. J. Nutr. 133:3717-3720. https://doi.org/10 .1093/jn/133.11.3717.

Taylor-Edwards, C. C., D. G. Burrin, J. J. Holst, K. R. McLeod, and D. L. Harmon. 2011. Glucagon-like peptide-2 (GLP-2) increases small intestinal blood flow and mucosal growth in ruminating calves. J. Dairy Sci. 94:888-898. https://doi.org/10.3168/jds.2010 $-3540$.

Van Soest, P. J., J. B. Robertson, and B. A. Lewis. 1991. Methods for dietary fiber, neutral detergent fiber, and nonstarch polysaccharides in relation to animal nutrition. J. Dairy Sci. 74:3583-3597. https://doi.org/10.3168/jds.S0022-0302(91)78551-2.

Villena, J., H. Aso, and H. Kitazawa. 2014. Regulation of toll-like receptors-mediated inflammation by immunobiotics in bovine intestinal epitheliocytes: Role of signaling pathways and negative regulators. Front. Immunol. 5:421. https://doi.org/10.3389/fimmu .2014 .00421

Wu, J., K. K. Qi, and Z. W. Xu. 2016. Porcince glucagon-like peptide-2 microspheres ameliorate inflammation in lipopolysaccharide-challenged weaning piglets. J. Anim. Sci. 94:5286-5294. https: //doi.org/10.2527/jas.2016-1007.

Xiao, T., S. Wu, C. Yan, C. Zhao, H. Jin, N. Yan, J. Xu, Y. Wu, C. Li, Q. Shao, and S. Xia. 2018. Butyrate upregulates the TLR4 expression and the phosphorylation of MAPKs and NK- $\kappa \mathrm{B}$ in colon cancer cell in vitro. Oncol. Lett. 16:4439-4447. https://doi.org/10 $.3892 /$ ol.2018.9201.

Xie, S., B. Liu, S. Fu, W. Wang, Y. Yin, N. Li, W. Chen, J. Liu, and D. Liu. 2014. GLP-2 suppresses LPS-induced inflammation in macrophages by inhibiting ERK phosphorylation and NK- $\kappa \mathrm{B}$ activation. Cell. Physiol. Biochem. 34:590-602. https://doi.org/10 $.1159 / 000363025$.

Yadav, H., J. Lee, J. Lloyd, P. Walter, and S. G. Rane. 2013. Beneficial metabolic effects of a probiotic via butyrate-induced GLP-1 hormone secretion. J. Biol. Chem. 288:25088-25097. https://doi.org/ 10.1074/jbc.M113.452516.

Zarrin, M., O. Wellnitz, H. A. van Dorland, J. J. Gross, and R. M. Bruckmaier. 2014. Induced hyperketonemia affects the mammary immune response during lipopolysaccharide challenge in dairy cows. J. Dairy Sci. 97:330-339. https://doi.org/10.3168/jds.2013 -7222 .

Zhang, R., W. Zhu, and S. Mao. 2016. High-concentrate feeding regulates the expression of inflammation-related genes in the ruminal epithelium of dairy cattle. J. Anim. Sci. Biotechnol. 7:42-55. https: //doi.org/10.1186/s40104-016-0100-1.

Zhao, C., G. Liu, X. Li, Y. Guan, Y. Wang, X. Yuan, G. Sun, Z. Wang, and X. Li. 2018. Inflammatory mechanisms of rumenitis in dairy cows with subacute ruminal acidosis. BMC Vet. Res. 14:135. https: //doi.org/10.1186/s12917-018-1463-7.

\section{ORCIDS}

M. Oba (1) https://orcid.org/0000-0001-8057-3500

K. Izumi ๑ https://orcid.org/0000-0002-9179-957X 